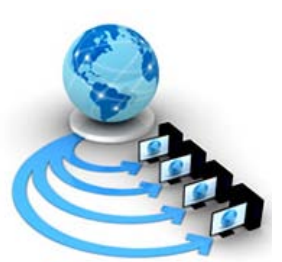

Volume 8, No. 8, September-October 2017

International Journal of Advanced Research in Computer Science

RESEARCH PAPER

\author{
Available Online at www.ijarcs.info
}

\title{
ADVANCE LEARNING SYSTEM WITH THE USE OF INFORMATION TECHNOLOGY
}

\author{
Dr.Jigneshkumar A.Chauhan \\ Assistant Professor \\ Department of Computer Science, Ganpat University \\ Kherva(North Gujarat),India
}

\author{
Dr.Satyen M.Parikh \\ Dean,FCA \\ Department of Computer Science, Ganpat University \\ Kherva(North Gujarat),India
}

\author{
Prof.Jigarkumar D.Patel \\ Assistant Professor \\ Department of Computer Science, Ganpat University \\ Kherva(North Gujarat),India
}

\begin{abstract}
As we know the teaching process in old days are very less effective and time consuming. Suppose let's understand it, if in computer application we want to discuss the topic input part of computer system in the class room than we have to draw it on a black board or white board. Than it may happen the figure is not same as we have seen in our text book or study material. So instead of this we can prepare presentation slide for input parts and explain it through projector, so it make more effective and less time consuming because no need to draw it on black board means we are saving the times and also we are make it affective because we have to take direct images.
\end{abstract}

Keywords: Advance Learning, Projector ,IT, Charts, Graphs

\section{INTRODUCTION}

In the old education system we are learning through the black board.

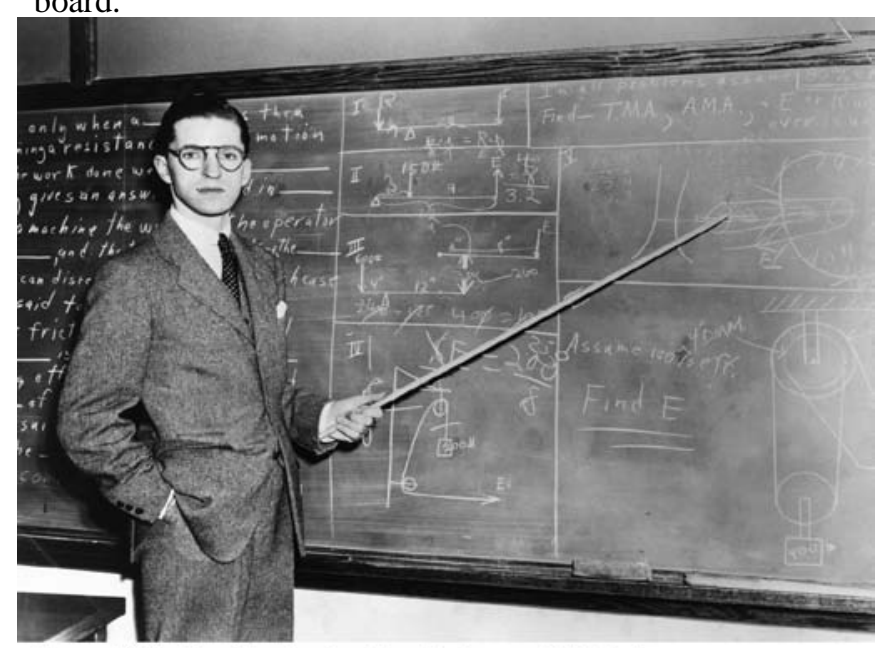

Figure:1930s Man Teacher Looking At Camera With Pointer

In the above figure it shows the old teacher teaches through use of black board and stick. For that he was first draw it inside black board then after he was discussing that topics. So for drawing it it need some time. It may happen some student's got not that thing which was he delivered to the students because of not proper figure.

In Figure 2 a lady teacher was teaches a child through the text book. She was shows to him the image in text book trying to make attractive learning for him. This thing is possible for single students but if the number of students are more than it is difficult to teach all students within the fix time period. So it was tedious and boring task for the old students because that was the only techniques at that time for education or learning system. Students have to learn it and if any problem occurs than for solving it they need some time for resolve it or very difficult to resolve it immediately.

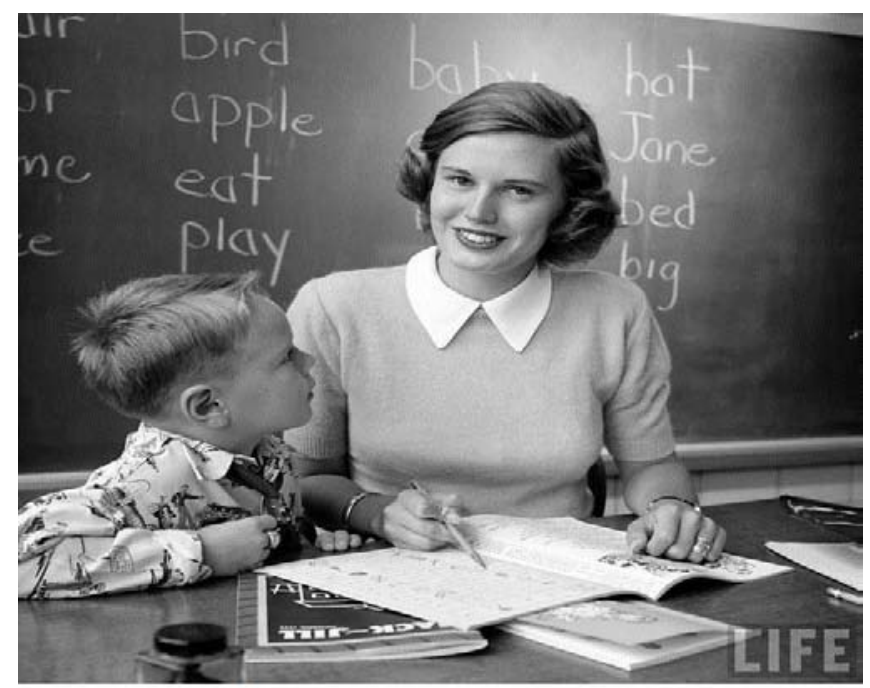

Figure 2:Old lady teacher teaches in 1930s

\section{OLD EDUCATION SYSTEM}

\section{A. Text Book or Reference Book}

A textbook or reference book is a handbook of education in any division or standard of teaching. Textbook is used as an ordinary work for the learning of a specific subject. Every standard have various subject and different contents. Every 
students have to come with text book and read it for exam and other preparation. Every standard have more than one subject so they have to come with many text book in a single days.

\section{B. Charts or Graphs}

A page or sheet showing information in the form of a table, graph, or diagram. An expanse giving statistics expressly in table form or a record of evidence for a record graph. A diagram, graph, image or diagram which is envisioned to make statistics easier to meaningful. For showing practically subject like physics, biology and other subject they use various charts for better understanding of students. So from the chart they can easily understand that concepts.

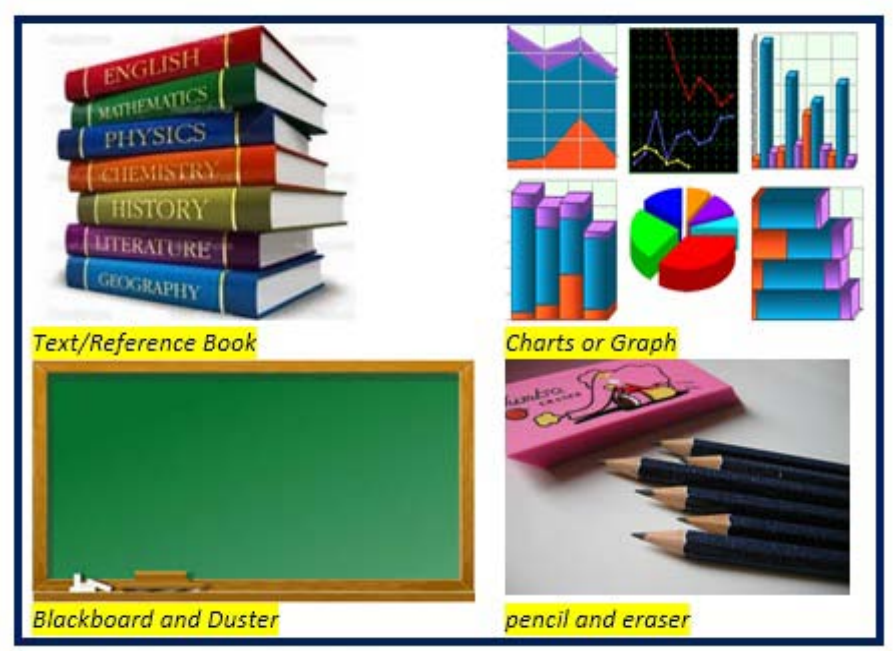

Figure 3 Old Education System

\section{Blackboard and Duster}

A Blackboard or Chalkboard duster (or eraser) is an extraordinary type of eraser unambiguously used to erase chalk designs on scheduling shade. It is most generally through of felt bands attached to an ergonomically designed handle. With the use of blackboard, teachers are writing the topic or content on board and students are learning from it.If board is full of text so for cleaning purpose eraser or duster is use.

\section{Pencil and Eraser}

Erasers have an elastic stability and originated in a several of shapes, sizes and colours.Certain pencils have an eraser on one end. Fewer expensive erasers are prepared from synthetic rubber and synthetic soy-based gum. A device for writing or drawing, consisting of a thin stick of graphite or a similar substance enclosed in a long thin part of wood or secure in a tubular case. Pencil is use for writing in note or paper and in between if anything is change or edit than eraser is use for erase it.

\section{ADVANCE LEARNING SYSTEM}

The advance new education system is use the latest technology and tools. This all tools are very user friendly and time savings. Students are not only study but also active them self during the learning system. In figure 4 it shows the old education system in that there are various parameter is there. Student is come in the school and use the content for the teaching in the classroom. Teacher was use the old teaching methods like drawing in the blackboard and discuss the topic also told to students for read from the book and ask question from in it or discuss what the contents shows in that text book or material.

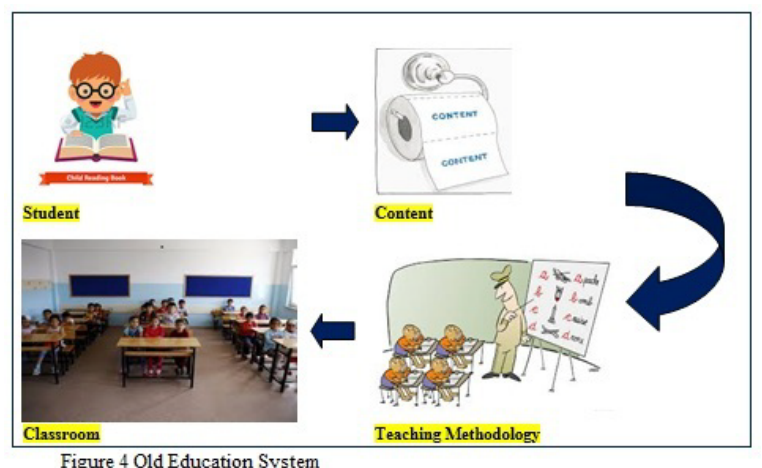

Advance lerning shows in the figure 5.In the advance learning we are using the following parameter which is shon in the bellow figure.

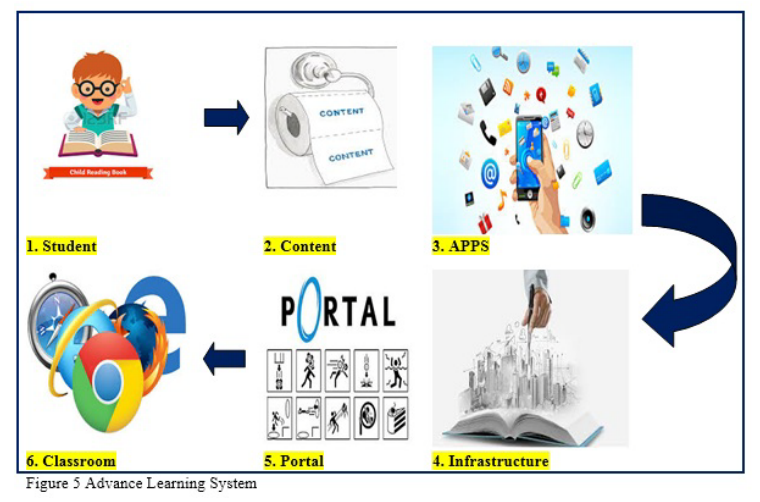

In Advance Learning system first studnets comes for the learning in that we the tutor teach through the content or through the apps.In the todays market various apps are availabele for the teaching educaton like if the nursery stuents wants to learn poem or rymes than the ready made apps are available.So we have to just download it as per our use,than install it and run it.For runing that apps it need infastructre means androiad mobile or tablets. The another way is web protal where everything is availabe as per various criateria means suppose if we want to learn any topic than as per topics web portal is available.Like one portal is for cocomputer technology so on that web portal there are so many solution is available for computer.Fo every portal we need good infastructure in ITIMS[1].

Suppose if you have a five class room and there are many students who are not present on that day due to some problem or any reason, so what to do for it that problem in old teaching education system we are facing. In new advance learning we know that our all class room are computerized and digital. Everything is now recorded in the CCTV camera with HD quality. So if any students were absent than they can got the details from the recorded video and go through it, and if any confusion they found than discuss with the teacher. So it save the times as well as the same thing which was delivered during the lecture that can be rewind it when they want.

For infrastructure we need the appropriate analysis and the requirement of the Organization. From that analysis we prepare the structure. Then we finalize estimate cost needed for it. Than finalize and submit it to higher authority for 
further process. Once we get confirmation from the higher authority we have to implement it as per analysis.

\section{LEARNING WITH IT MODEL}

The model defines how education takes place for a crowd of individual beginners through the educational experience that occurs at the intersection of public, thinking and teaching.

Public Attendance: is the capability of members to project their separate behaviours in instruction to recognize and converse with the community and progress inter-personal associations. (Garrison, 2009)

Thinking Attendance: is the extent to which beginners are able to paradigm and settle import through continual replication and treatise. (Garrison, Anderson, \& Archer, 2001, 2004)

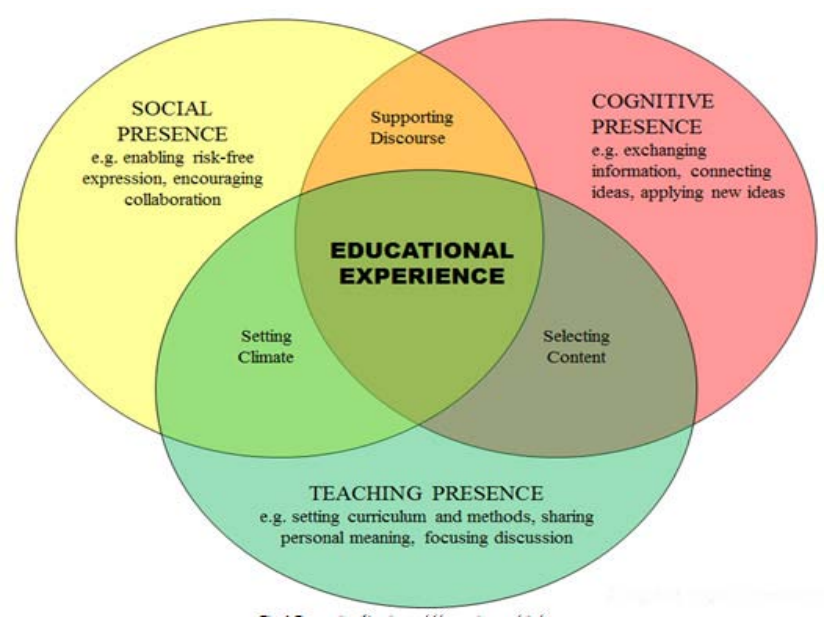

Figure 6 Learning Model for Education

\begin{tabular}{|l|l|l|}
\hline \multicolumn{1}{|c|}{ Design Elements } & \multicolumn{1}{c|}{ Student Experience } \\
\hline $\begin{array}{l}\text { Social } \\
\text { Presence }\end{array}$ & $\begin{array}{l}\text { Communication } \\
\text { Group Cohesion } \\
\text { Collaboration }\end{array}$ & $\begin{array}{l}\text { Valuing of Learning } \\
\text { Opportunity to Express Views } \\
\text { Encouraging Collaboration }\end{array}$ \\
\hline $\begin{array}{l}\text { Cognitive } \\
\text { Presence }\end{array}$ & $\begin{array}{l}\text { Challenge or question } \\
\text { Exploration of problem } \\
\text { Proposing solutions } \\
\text { Resolution }\end{array}$ & $\begin{array}{l}\text { Sense of Puzzlement } \\
\text { Information Sharing } \\
\text { Connecting Ideas } \\
\text { Apply New Ideas }\end{array}$ \\
\hline $\begin{array}{l}\text { Teaching } \\
\text { Presence }\end{array}$ & $\begin{array}{l}\text { Instructor Guidance } \\
\text { Building Understanding } \\
\text { Motivating }\end{array}$ & $\begin{array}{l}\text { Defining and Initiating Discussion } \\
\text { Topics Sharing Personal Meaning } \\
\text { Focusing Discussion }\end{array}$ \\
\hline
\end{tabular}

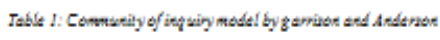

Education Attendance: is the design, simplification, and route of the public and intellectual methods for the resolve of understanding the applicable education results (Anderson, Rourke, Garrison, \& Archer, 2001)[2].

\section{VIRTUAL LEARNING}

Virtual learning permits pupils to connect, interact, share and acquire with others outside of their schoolroom. Virtual learning can be synchronous, where all pupils log in at the one time in a virtual classroom, or it can be asynchronous, where scholars access term recordings in their particular time [3].

\section{REFERENCES}

[1] Faten Karim,Dr.Robert Goodwin "Using Cloud

[2] Computing in E-learning Systems" Vol. 1 Issue 1 Oct-Dec 2013 IJARCST

[3] Dr.Jigneshkumar A. Chauhan, Mr.Jigarkumar D.Patel "Models of online learning" Vol. 6 Issue 8 August 2017 IJAIR

[4] A Virtual Learning Environment(VLE)

[5] http://whatis.techtarget.com/definition/virtual-learningenvironment-VLE-or-managed-learning-environment-MLE 